\title{
Augmented reality and CMMS as mechanisms to increase productivity in smart factories
}

\section{La realidad aumentada y los CMMS como mecanismos para aumentar la productividad en las fábricas inteligentes}

TORRES-TINOCO, Anahí Montserrat*†ं, SANCHEZ-DURAN, Ricardo Miguel and LÓPEZ-SEGURA, Teresita

Universidad Tecnológica de León, Área Tecnologías de la Información. Blvd. Universidad Tecnológica \#225 Col. San Carlos León, Gto. México.

ID $1^{\text {st }}$ Author: Anahi Montserrat, Torres-Tinoco / ORC ID: 0000-0001-5625-8076 Researcher ID: T-5748-2018, arXiv ID Author: AnahiTinoco, CVU CONACYT ID: 236283

ID $1^{\text {st }}$ Coauthor: Ricardo Miguel, Sanchez-Duran / ORC ID: 0000-0001-8742-2879, Researcher ID: G-1904-2019, CVU CONACYT ID: 972644

ID $2^{\text {nd }}$ Coauthor: Teresita, López-Segura / ORC ID: 0000-0001-5801-952X, Researcher ID: T-6804-2018, arXiv ID Author: tlopez\#3, CVU CONACYT ID: 683314

DOI: $10.35429 / J M M E .2019 .5 .3 .7 .13$

Received August 19, 2019; Accepted December 18, 2019

\begin{abstract}
Augmented reality is one of the technologies that with a high frequency is involved in the theme of Industry 4.0 for its benefits, however, it is applied more frequently in entertainment areas, when it is a tool that allows to show data, pieces, statistics, technical data sheets of industrial equipment thus revolutionizing the manufacturing industry and to another way to show of data in this field. This article shows the exploration of the combination of augmented reality, with a CMMS with the purpose of serving as a strategic information system for decision giving the manufacturing company the concept of intelligent factory in the ecosystem of the industry 4.0. The CMMS is developed first, then the augmented reality application is created and finally the study is done to verify if they are compatible and if the presented information is useful for the company. The contribution of this study is to propose a methodology for the development of a new type of strategic information system 4.0 in which a new way of displaying data (AR) and an information system such as CMMS is mixed.
\end{abstract}

\section{Resumen}

La realidad Aumentada es una de las tecnologías que con una alta frecuencia se ve involucrada en el tema de Industria 4.0 por sus beneficios, sin embargo, se aplica con mayor frecuencia en áreas de entretenimiento, cuando es una herramienta que permite mostrar datos, piezas, estadísticos, fichas técnicas de equipos industriales revolucionando así la industria manufacturera y en gran medida la presentación de datos en este ramo. En este artículo se muestra la exploración de la combinación de la realidad aumentada, con un CMMS con la finalidad de servir como un sistema estratégico de información para la toma de decisiones dando a la empresa manufacturera el concepto de fábrica inteligente en el ecosistema de la industria 4.0. Se desarrolla primero el CMMS, posteriormente se crea la aplicación de realidad aumentada y finalmente se hace el estudio para verificar si son compatibles y si la información presentada es útil para la empresa. La contribución de este estudio es proponer una metodología de desarrollo de un nuevo tipo de sistema estratégico de información 4.0 en la que se mezcle una nueva forma de mostrar datos (AR) y un sistema de información como el CMMS. and monetary economy. 2019. 3-5: 7-13.

\footnotetext{
* Correspondence to Author (email: antorres@utleon.edu.mx)

$\dagger$ Researcher contributing first author.
} 


\section{Introduction}

From the moment the internet ceased to be only information for people due to sensors in machines and robots, or what we know as the internet of things, industries have been concerned with applying these strategies in new areas of This disruptive way.

Industrial maintenance is an important element in the production process in companies, since it provides mechanisms so that production remains safe and cost-effective. The Centralized Maintenance Management System (CMMS) are useful information systems for storing data from the management of the maintenance department from the registration of machinery to the registration of preventive plans. This need for management decision-making information is what drives many companies to use systems that have a high impact. However, the way of presenting the information is sometimes not the clearest for the user. Multimedia strategies such as virtual tours, augmented reality are strategies that can be applied to systems in order to display information differently.

The concept of industry 4.0 was first heard in Germany, in an event of industrial innovation, when they referred rather to the topic "Smart Industry" in which the definition mentioned the use of multiple sensors, robotics and information systems that They allow new models to organize the industry, which led to the talk of the fourth industrial revolution. [Kagermann, 2017].

This document proposes the possibility of linking a CMMS with augmented reality to present useful reports in decision making in such a way that a better user experience is generated that responds to usability and accessibility. The use of Augmented Reality, with a CMMS system is the added value, since it contributes to the pillars of industry 4.0.

The first topic of this document presents the development of intelligent factories, as well as of industry 4.0 from the perspective of several authors starting from their origin to the elements and tools of the same.

The second topic presents a compilation of applications in the industry in which augmented reality facilitates processes.
The CMMS concept is defined in the third topic of this document, as well as the system developed for the company that facilitated the development. The methodology section briefly describes how the architecture proposed here was developed, from the development of the CMMS, as well as the integration with Unity until reaching the application of Augmented reality with Vuforia. Finally, the results and conclusions generated after this investigation and implementation are presented.

\section{Smart Factories and Industry 4.0.}

First world countries are looking for strategies that help put their industries at a level that allows global competition, including Germany, Korea and the United States. The gathering of information technologies, the application of sensors and robotics to make way for the internet of things, is not the only thing these companies care about, but also pay attention to the needs of customers, since it seeks the customization and creation of new products and / or services with quality and that provide a better consumer experience. That is why Industry 4.0 is based on ICT, as it is what allows intelligence in the same factories.

The intelligent factory or Smart Industry or connected Industry, is represented by the type of CPPS systems, which are information systems with sensors, machinery and some other equipment used in production with an interaction that makes operators only get involved for maintenance tasks. This exceptional communication between the machines and the systems allows them to configure themselves to adapt in real time to the needs of the client, improving their experiences in all the life cycle processes of these products or services. In these smart factories, all systems are interconnected in agent networks that make their own data-based decisions.

Apart from smart factories, industry 4.0 has other fundamental pillars such as: cloud computing, big data, internet of things, robotics, security protocols and augmented reality. The latter allows a type of systems in which, digital information is superimposed over real-time vision, useful information is shown for decision making or about work procedures. 
It is intended that with this tool there are systems that, through augmented reality lenses, employees can perform an increased repair, thus increasing safety and efficiency. [Del Val, 2015]. The exponential production and sale of mobile devices, from wearebles, has allowed us to see more and more this technology in professional life. Also 3D modeling and virtual reality has allowed to recreate spaces, models, products, people and machines in a virtual mirror model of a real world.

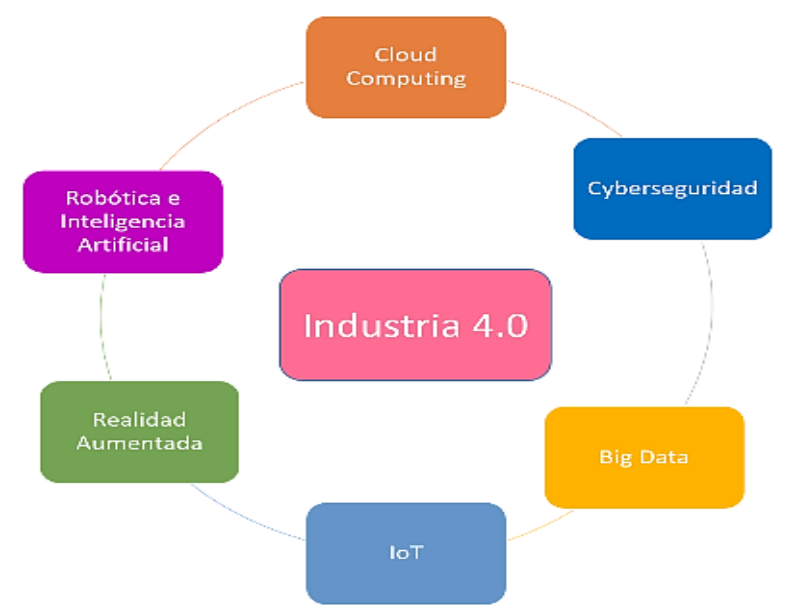

Figure 1 The pillars of Industry 4.0

We can define the benefits that large corporations enlist in this fourth revolution in 4 fundamental aspects: an added value is given to the company, a stabilizing effect is generated in the administrative management and production of the company, profits are multiplied, production, sales, customers etc, and this helps to generate more exports and imports. However, the most important thing that when using the aforementioned technologies, companies will move from mass production model to mass customization and above all leads companies to think about new business models in which manufacturing may be Distributed and largely allow efficiency in operations to mention, sustainability, security, inventories, customer service and without a doubt productivity. [Ramon and Cajal, 2016]

\section{Augmented Reality applied in the industry}

Augmented reality has been of great impact in recent times when users are betting on all those more visual and interactive applications. Its use is very varied, from academics, medicine and industry.
Speaking of the industry, through the use of Augmented Reality (RA), manufacturers or service personnel, using I or T mechanisms can identify an object, equipment or machinery to obtain any information from the enterprise resource planning system. Building the best connection between the information systems and the RA, the technician will have immediate access to the specifications, inventory, location and delivery times of the object. Augmented reality is a very powerful tool for the development of personnel training, since it is possible to access the technician or operator to the instructions and manuals that provide operational details. It is also possible to run videos while working on a process, which facilitates the specialization of personnel, for example, this can be used in an assembly line since personnel with little knowledge can learn when performing the process without the employee requires a degree of specialization; All this is achieved because with the RA the information or instructions can be superimposed. Specifically in the maintenance area, this becomes useful for checking at what time the machines or equipment are working correctly or preventing maintenance for observed details. The technician will see the real problem before approaching the machine, since, thanks to the I or $\mathrm{T}$, the sensors of the machine will have sent advance information, which saves time and money when diagnosing failures. Also the augmented reality can help in the industry in the realization of tests of quality in the pieces since, if they present a deficiency, it could be determined if they are salvageable or should be replaced. [Olive 2018]

In order to create augmented reality, it is necessary to know the options for this, which by the way are increasingly more than one would think and many of them without knowing any programming, among them we find Aumentaty, Google also has its contribution with ARCore, Metaverse and Vuforia, the latter is a software for more prepared developers more advanced users and who have previous knowledge of programming and computing. 
In general, as mentioned before, the uses of augmented reality in the industry improve the user experience by making activities more and more immersive, so we can see systems such as the DMG solution for Industry 4.0 of the company SCS Concept Group, which is an augmented reality system for manufacturing processes, that is, it includes a complete guide for the operator on how to assemble a device, in case you make a mistake, the augmented reality system marks a message. There is also another RA system that, connected to an information system, is able to mention the inventory of available parts, how many are available to fill orders, etc. The Paccar company also made use of augmented reality, building an application that allows defining the characteristics of a trailer, from the definition of headlights, the chest and the box. Mercedes Benz is another brand that is betting on this technology using an application that trains users in the chassis assembly of some of their cars. Tecnalia is a software based on this technology that helps in the training for the assembly of computers mentioning step by step that must be armed. There are also many equipment manuals made in $3 \mathrm{D}$ and that with augmented reality show their characteristics. There are other applications in which you can define technical information about different equipment.

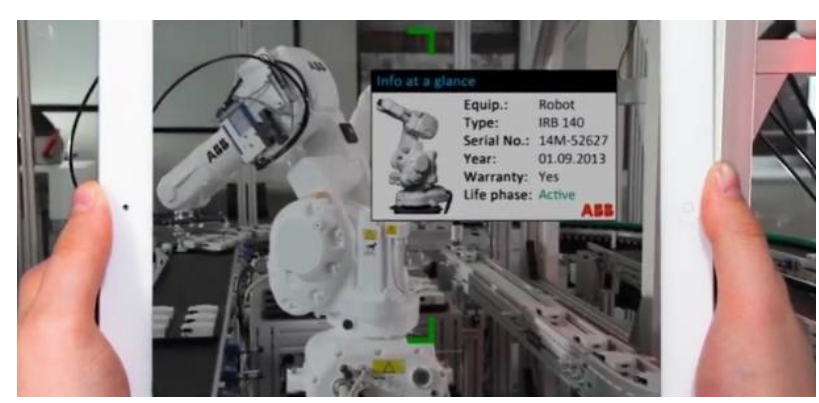

Figure 2 Manuals in Augmented Reality

\section{CMMS}

Maintenance is a very important point in the industries because it aims directly to boost production or affect it, this means a constant search for new and innovative ways to increase the reliability, availability and useful life of plants, that is to say, to implement the concept of intelligent plants.
The automation and use of technologies has allowed the planning and programming of maintenance work on large volumes of equipment, machinery and facilities, which marks the need to use large information systems such as CMMS Business Planning Maintenance Systems. This type of systems allows the classification and characterization of information, so that it is grouped and consulted according to the specific requirements of each user, which facilitates the processes of analysis and decision making, so important in the areas of costs and reliability. An essential feature in CMMS is that they can provide data such as the average time in which the equipment fails, or the time it is maintained. This average failure time indicator measures the time in which a device can be operated without failures, that is, work continuously, which allows reliability in the equipment. Another important indicator in a CMMS is the average time at which the equipment or Mean Time To Repair (MTTR) is repaired, which is nothing other than the measure of the distribution of the repair time of an equipment or system. This indicator measures the effectiveness in restoring the unit to optimal operating conditions once the unit is out of service due to a failure, within a certain period of time. The measurement of faults and their analysis is a characteristic of an optimal maintenance system, which means that the values of the equipment in question must be recorded at all times during its useful life. [Amendola, 2017]

In this document we want to mention the development of a CMSS for a Leon company dedicated to the manufacture of dyes and paints. They had the need to manage maintenance and thus be able to have accurate information about the failures. It was developed by teachers and some students [Hernandez, 2018].

It was developed using project management methodologies with CMMI and PMBOOK practices. 3 iterations were performed.

It was developed with HTML, Bootstrap, JavaScript client-side programming, Ajax and server-side programming using PHP and MySQL database. In addition to having an MVC architecture. 
This CMMS includes the sections of: Catalogs (Equipment, Tools, Supplies, Technicians, Profiles, Locations and Users), Service Management, Corrective Maintenance Management, Preventive Maintenance Management and Reports. This system includes permission management, sessions by type of user. Packages such as Data table were used that allow the visualization of data in selfmanageable reports by the user, allowing the export to Excel, pdf, copy and paste etc.

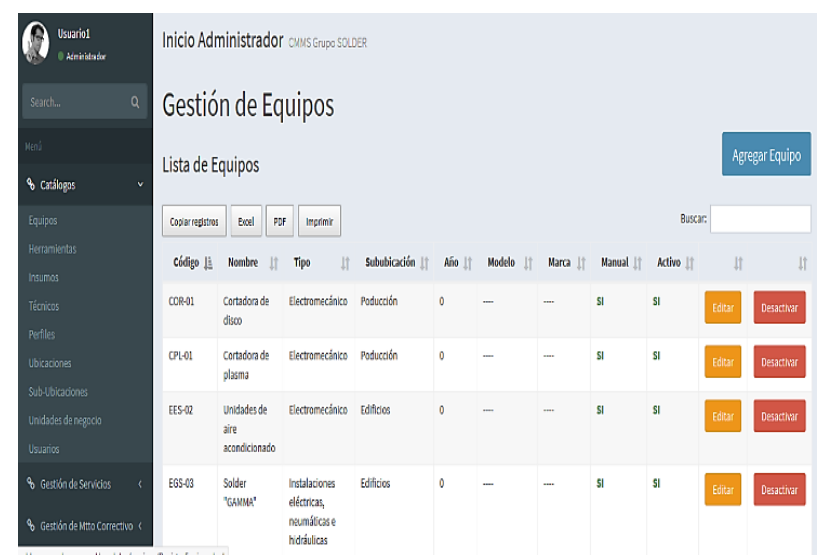

Figure 3 CMMS screen developed

This system is currently in use and already has real records, the company has given a value to the system and this is the only way to record its maintenance-related operations. Among the needs currently marked by the client is to add a section of reports that give a clearer perspective of data such as failures, attention time, hours paid for staff etc. This information is used so that management can make decisions, so it is proposed that this section be the one shown with augmented reality.

\section{Methodology to be developed}

The development of this CMMS application and augmented reality is defined in 3 phases, in the first one the information system is built that will allow the registration of the necessary data about maintenance. Several stages of analysis were defined for the collection of software requirements, subsequently the stage of modeling use cases was mainly developed, database diagramming and application wireframes.

\begin{tabular}{|l|l|}
\hline ID DE CASO DE USO & CU_RFO3 \\
\hline $\begin{array}{l}\text { NOMBRE DE CASO DE } \\
\text { USO }\end{array}$ & Proceso Catálogo de Téenicos. \\
\hline DEPENDENCIA & N/A. \\
\hline $\begin{array}{l}\text { DOCUMENTOS } \\
\text { RELACIONADOS }\end{array}$ & CuestionarioBase.doc, Requerimientos.xlsx, \\
\hline RESPONSABLE & Anahi Torres Tinoco \\
\hline ACTORES & Encargado de mantenimiento-Administrador de la Aplicación \\
\hline $\begin{array}{l}\text { DESCRIPCIÓN } \\
\text { GENERAL }\end{array}$ & $\begin{array}{l}\text { Permititra almacenar en el sistema CMMS los técnicos que integran el } \\
\text { departamento. }\end{array}$ \\
\hline
\end{tabular}

Table 1 Use case detail

The coding stage was attended by modules, the catalogs were first made, then the service management and finally the corrective and preventive maintenance management section. Each of these stages carried out a verification with the company.

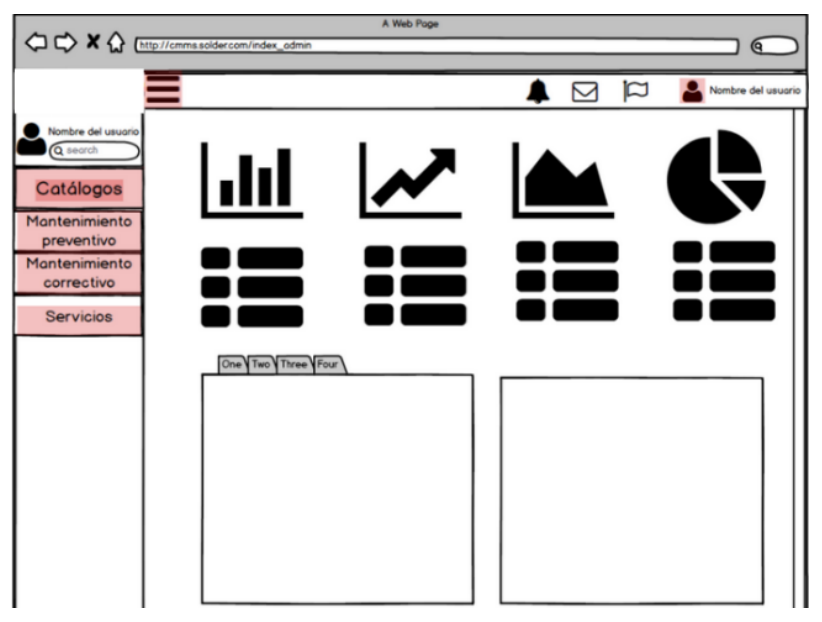

Figure 4 CMMS wireframe

This first stage was evaluated in each delivery, that is, at the time of delivering each module the user performed tests and the development team performed functionality and performance tests previously. As mentioned earlier, CMMS is already in use.

The second stage of this methodology is to develop the communication environment with the augmented reality system. In this stage the first thing that was done is to select the development environment for the virtual application that in this case is Unity, the connection that would be made is to a server since there are the MySQL databases it is important that this server already It is placed on the internet, however, a suite like WAMP that does a local service can work. The database is created, in the case of the application mentioned here, the database used by the CMMS will be used. Subsequently it is necessary to create a PHP file that includes the connection to that database. 
Achieving communication it is necessary to bring the data to be displayed, in this case it is the data resulting from maintenance reports. In Unity you must create a script that includes interface elements, adding the UnityEngine.UI class. It also makes use of the IEnumerator class that allows you to use the www object and will receive the URL of the PHP file that achieves the connection to the server as a parameter. From PHP we will return a string that includes all the data to display, when receiving them in Unity objects will be created that represent the bar graphs in which you only have to change the scales according to the values that come from the database. Finally, these elements are displayed in Vuforia so that when reading the CMMS tags you can throw the graphics in augmented reality. The last stage of this methodology is the performance of the corresponding usability, functionality and performance tests.

\section{Results}

There is currently a CMMS Se in iteration 1, 2.3 on a remote server owned by the company; It is not possible to share any content, because it is private property protected by confidentiality agreements. It includes $n$ real data of the company, in which it is necessary to make the relevant changes to have a better functioning of the augmented reality section. The company that requests the development is committed and interested in the implementation of these new technologies. The Augmented Reality implementation phase is still under development since it depends on the reports requested by the company and especially on the generation of tags to show augmented reality.

\section{Acknowledgments}

We thank the company Grupo Solder of the City of León Guanajuato, who kindly requested the services of the professors and research professors of the Virtual Environments and Digital Businesses career to develop this application and rely on our performance. Also to the Technological University of León for providing research hours for the realization of this type of projects and finally to all our students who somehow participated in the realization of this project, from section modeling, programming and testing.

\section{Conclusions}

From the point of view of teachers, with a research profile some of the benefits can be described when participating in this project: the vital importance of working with a company motivates the teaching staff to remain updated in the knowledge of process architecture; to be able to propose more business scenarios not so much as simulations inside the classroom; It is a time to see the use of the technologies seen in the classroom implemented in the industry and above all by paying for this 4 th industrial revolution.

This project of linking a CMMS with Augmented Reality demonstrates that RA applications are not only used for entertainment, but have a high impact on the industry. Industries seek to obtain greater benefits using technologies representative of industry 4.0. but they know that it is necessary to have strategic plans in which they set goals that they intend to reach.

Finally another important change will come in the workers since they will have to learn to live with different ways of interaction with the environment and the machines due to the physical cyber systems, and on the other the consumers, the relationship with the company and the way of buying, Will be affected.

Higher levels of customization will be obtained, and shorter wait times will be required in the same way.

\section{References}

Kagermann H. (2017) Chancen von Industrie 4.0 nutzen. In: Vogel-Heuser B., Bauernhansl T., ten Hompel M. (eds) Handbuch Industrie 4.0 Bd.4. Springer Reference Technik. Springer Vieweg, Berlin, Heidelberg.

Del Val Roman, José Luis, (2015). Industria 4.0: la transformación digital de la industria. Conferencia de directores y Decanos de Ingeniería Informática. Universidad de Deusto.

López Ramón y Cajal Jorge, Escudero Ceballos Víctor. Industria 4.0 La gran Oportunidad. Economía Aragonesa, Número 59. abril 2016 
Amendola, Luis. Indicadores de Confiabilidad propulsores en la gestión del mantenimiento. Universidad Politécnica Valencia España. 2017.

Oliva Navarro Edgar. Industria 4.0 Retos y oportunidades en las Factorías de Automoción. Escuela de Ingenierías Industriales. Valladolid 2018.

Hernández-Irastorza, Luis Ricardo, LópezSegura, Teresita de Jesús y Torres-Tinoco, Anahí Montserrat. "Educación dual como un modelo para el desarrollo de habilidades y destrezas en equipos colaborativos interuniversitarios dedicados al desarrollo web en la nube. Revista de Teoría Educativa. ISSN 2523-2509, Perú 2018 